\title{
Giant Solitary Trichilemmal Cyst of the Upper Eye Lid: Masquerading Lacrimal Gland Tumor: A Clinico Radio Pathological Case Report
}

\author{
Anita $\mathrm{P}^{1 *}$, Nandita $\mathrm{C}^{1}$ and Saita ${ }^{2}$ \\ ${ }^{1}$ Department of Ophthalmology, Sharda Hospital, India \\ ${ }^{2}$ Department of Pathology, India
}

Submission: July 21, 2017; Published: August 21, 2017

*Corresponding author: Anita Panda, Department of Ophthalmology, Sharda Hospital, Greater Noida, India, Email: anitap492004@yahoo.com

\author{
Abstract \\ Purpose: To report a case of giant solitary trichilemmal cyst in a 58-year-old man. \\ Design: Observational case report. \\ Methods: A 58-year-old man sought treatment for a mass in the right upper eyelid. The lesion was excised and examined \\ histopathologically.
}

Results: Light microscopy showed a cystic lesion lined by stratified squamous epithelium with a compact layer of eosinophilic keratin without granular cell layer. There was no atypia, mitosis, or stromal invasion.

Conclusion: Solitary trichilemmal cyst is rare in comparison to multiple cyst. To the best of our knowledge, this is the first case report of trichilemmal cyst masquerading as Lacrimal Gland Tumor which was managed by surgical excission.

\section{Introduction}

Trichilemmal cyst, also known as a pilar cyst, forms from the outer root sheath of hair follicle. They are common benign tumors most often found on the scalp [1]. The involvement of the eyelids is quite rare. It presents as a smooth, firm, mobile, and round nodule without a visible punctum. There is often an autosomal dominant inheritance pattern as the lesion is frequently familial [2]. Till now, there are only few case reports of trichilemmal cyst of the eyelid [3-6].

\section{Case Report}

A 58 year old mahemedian male from Bulendsar, UP, India was referred to Sharda Hospital because of a persistent static small swelling upper lid for last 10 years which is progressively increased over last three months. It was horizontally disposed [7-8], approximately $12 \mathrm{~mm} / 8 \mathrm{~mm}$ in horizontal and vertical dimension. According to the patient this tumour first appeared as upper lid nodule. But for the last three months, it was growing rapidly and he was unable to open the eyelid. Patient developed ptosis and difficulties in vision due to large tumour and weight of the mass. There is drooping of upper eye lid since then. He is a non vegeterian and none of his family members had similar problem. An ophthalmic examination revealed a visual acuity of 20/40 in each eye due to presence of cataract which was not improved with pin hole or refraction [9-10]. The right upper lid has covered total cornea and almost 3/4th of palpebral apperature. A closer examination of anterior segment of both eyes were apparently normal expect early cataractous changes. Both the fundii were normal.

Examination of upper lid showed a large swelling arising from the upper lid, involving the 1/3rd of the right upper lid. Surface was smooth, overlying skin stretched. The mass was not with any surface blood vessels, with no colour or temperature changes, no expansible impulse on coughing and on auscultation no bruit was heard. Texture of the tumour mass was firm and solid. Intra Ocular Pressure by Applanation Ton+ometry was $16 \mathrm{~mm}$ hg in both the eyes. Schirmer value was $18 \mathrm{~mm}$ and that of BUT 14 in both the eyes. Plain X Ray of right orbit showed a large, well-defined, solid solitary mass at lateral aspect of 
upper lid just adjacent to lacrimal gland. measuring $3.1 \times 2.1 \mathrm{~cm}$, over Routine Blood Investigations were within normal limit A clinical diagnosis of epithelial cyst was made. The patient under wentan excisional biopsy of the right upper lid. A skin incision was made along the lid crease [11-12], the skin was undermined over the mass which was unexpectedly easy in view of its adherence to mass on preoperative examination and the mass was easily separated from the underlying orbicularis. The mass was removed in to and primary skin closure was done. The excised mass was white in color. Post operatively, the lid contour was normal and there was no ptosis. No recurrence or evolution of new lesion was noted on follow-up. The patient is highly satisfied for cosmetic and free of growth. Histopathological examination of the specimen revealed the mass was lined by stratified squamous epithelium that lacks a granular cell layer and was filled with compact «wet» keratin.

(A) Clinical photograph of the right eye showing a growth over lateral aspect of upper lid with ptosis

(B) Photomicrograph from the removed growth showing

(haematoxylin and eosin, original magnification $\times 250$, inset $\times 325$ ).

\section{Comment}

Trichilemmal cysts of the body may run in families and they may or may not be inflamed. They are solitary in $30 \%$ of cases and multiple in $70 \%$ of cases. These cysts are derived from the outer root sheath of the hair follicle. Their origin is unknown, but it has been suggested that they are produced by budding from the external root sheath as a genetically determined structural aberration. They arise preferentially in areas of high hair follicle concentration, therefore, $90 \%$ of cases occur on the scalp. Rarely, these cysts may grow more extensively and form rapidly multiplying trichilemmal tumors, also called proliferating trichilemmal cysts, which are benign but may grow aggressively at the cyst site. Very rarely, trichilemmal cysts can become malignant. They are lined by stratified squamous epithelium that lacks a granular cell layer and are filled with compact "wet" keratin. Areas consistent with proliferation can be found in some cysts. In rare cases, this leads to formation of a tumor, known as a proliferating trichilemmal cyst. The tumor is clinically benign, although it may display nuclear atypia, dyskeratosis, and mitotic figures which often can be mis leaded as the diagnosis of squamous cell carcinoma. Surgical excision is the only mode of management.

\section{References}

1. Adachi N, Yamashita T (1990) Trichilemmal cyst of the scalp: MR imaging. AJR Am J Roentgenol 154(2): 423-424.

2. Karuppannan B, Shaharuddin B, Zunaina E (2009) Trichilemmal cyst in the eyelid: a rare presentation. International Journal of Ophthalmology 9(8): 1451-1452.

3. Perrez LM, Bruce JW, Murrah VA (1997) Trichilemmal cyst of the upper lip. Oral Surg Oral Med Oral Pathol Oral Radiol Endod 84(1): 58-60.

4. Elder D, Elenitsas R, Ragsdale B (1997) Tumors of the epidermal appendages, in Lever's Histopathology of the Skin. In: Elder D, Elenitsas R, Jaworsky C, Lippincott W, Wilkins (Eds.), Philadelphia, USA, pp. 749799.

5. Leppard BJ, Sanderson KV (1976) The natural history of trichilemmal cysts. Br J Dermatol 94(4): 379-390.

6. Meena M, Mittal R, Saha D (2012) Trichilemmal cyst of the eyelid: Masquerading as recurrent chalazion. Case Rep Ophthalmol Med 2012: 261414.

7. Jakobiec FA, Mehta M, Sutula F (2009) Keratinous cyst of the palpebral conjunctiva. Ophthal Plast Reconstr Surg 25(4): 337-339.

8. Satyaprakash AK, Sheehan DJ, Sangüeza OP (2007) Proliferating trichilemmal tumors: A review of the literature. Dermatol Surg 33(9): 1102-1108.

9. Lai TF, Huilgol SC, James CL, Selva D (2003) Trichilemmal carcinoma of the upper eyelid. Acta Ophthalmol Scand 81(5): 536-538.

10. Kang SJ, Wojno TH, Grossniklaus HE (2007) Proliferating trichilemmal cyst of the eyelid. Am J Ophthalmol 143(6): 1065-1067.

11. Lee SJ, Choi KH, Han JH, Kim YD (2005) Malignant proliferating trichilemmal tumor of the lower eyelid. Ophthal Plast Reconstr Surg 21(5): 349-352.

12. Mendoza PR, Jakobiec FA, Yoon MK (2013) Keratinous cyst of the palpebral conjunctiva: New observations. Cornea 32(4): 513-516.
Your next submission with Juniper Publishers will reach you the below assets

- Quality Editorial service

- Swift Peer Review

- Reprints availability

- E-prints Service

- Manuscript Podcast for convenient understanding

- Global attainment for your research

- Manuscript accessibility in different formats

( Pdf, E-pub, Full Text, Audio)

- Unceasing customer service

Track the below URL for one-step submission https://juniperpublishers.com/online-submission.php 